\title{
Hubungan Kepatuhan Konsumsi Obat Antidiabetes dengan Kesehatan Jaringan Periodontal pada Pasien Prolanis Diabetes Melitus Tipe II: Studi Kasus di Puskesmas Mranggen III
}

\section{Compliance Relation of Antidiabetic Drug Consumption with Periodontal Network Health in Type II Diabetes Mellitus Prolanis Patients: Case Study at Puskesmas Mranggen III}

\author{
Hesti Widyawati, ${ }^{1}$ Sudibyo, ${ }^{1}$ Hayyu Failasufa ${ }^{2}$ \\ ${ }^{1}$ Fakultas Kedokteran Gigi, Universitas Muhammadiyah Semarang. \\ 2Program Studi Magister Epidemiologi, Pascasarjana Universitas Diponegoro \\ Fakultas Kedokteran Gigi, Universitas Muhammadiyah Semarang. \\ Jl. Kedungmundu Raya No.22 Semarang, Email : hesti.widyawati@gmail.com
}

\begin{abstract}
Abstrak
Latar belakang : Penyakit periodontal adalah keadaan patologis yang mengenai jaringan periodontal. Faktor penyebab penyakit periodontal dapat dikelompokkan menjadi dua, yaitu faktor lokal dan faktor sistemik. Diabetes dan periodontitis adalah penyakit yang saling berhubungan dan termasuk dalam penyakit kronis yang kompleks. Bukti bahwa kadar gula dalam darah yang tinggi pada penderita diabetes melitus dikaitkan dengan kesehatan jaringan periodontal yang buruk. Pencegahan komplikasi dengan cara menjaga kestabilan gula darah dengan pengobatan secara rutin seumur hidup. Hal tersebut karena diabetes melitus merupakan penyakit seumur hidup yang tidak bisa disembuhkan secara permanen sehingga banyak pasien yang jenuh dan tidak patuh dalam pengobatan. Ketidakpatuhan pasien dalam konsumsi obat antidiabetes meningkatkan resiko komplikasi dan bertambah parahnya penyakit yang diderita. Penelitian ini bertujuan untuk mengetahui hubungan kepatuhan konsumsi obat antidiabetes dengan kesehatan jaringan periodontal pada pasien Prolanis DM tipe II di Puskesmas Mranggen III. Penelitian ini memeriksa kesehatan jaringan periodontal dengan indeks CPITN dan indeks gingiva serta menilai kepatuhan konsumsi obat antidiabetes dengan kuisioner Modified Morisky Scale.
\end{abstract}

Metode:Metode penelitian adalah observasi analytic dengan desain cross-sectional. Pengambilan sampel menggunakan metode accidental sampling. Uji analisis data dengan uji korelasi Spearman Rho (@).

Hasil : Jumlah sampel yang diperoleh 36 orang, dengan 86,2\% pasien patuh dan 13,8\% pasien tidak patuh dalam konsumsi obat antidiabetes. Pasien yang memiliki kesehatan periodontal yang sehat 33,3\%, sedang 52,8\%, dan buruk 13,9\%. Terdapat korelasi antara kepatuhan konsumsi obat antidiabetes dengan kesehatan jaringan periodontal (nilai $\mathrm{p}=0,000 ; \mathrm{p}<0,050$ ).

Simpulan : Terdapat hubungan antara kepatuhan konsumsi obat antidiabetes dengan kesehatan jaringan periodontal.

Kata Kunci : Kepatuhan konsumsi obat antidiabetes, kesehatan jaringan periodontal, pasien PROLANIS $\mathrm{DM}$ 


\begin{abstract}
Background :Periodontal disease is a pathologic condition on the periodontal tissue. Generally, the cause of this disease can be divided into two factors: local factor and systemic factor. Diabetes and periodontal are connected each other and are included as chronic and complex diseases. The evidence of the high sugar amount in the diabetics blood is related to the poor health condition of the periodontal tissue. The prevention of the complication can be done by keeping the stability of the blood sugar through routine medical treatment. This is needed because diabetes mellitus(DM) is a lifelong disease which cannot be cured permanently. Many patients are tired and not obedient towards the treatment. Disobedience of the patient in consuming antidiabetic medicine increases the risk of complications and the disease severity. The objective of this research was to know the relation between the obedience of antidiabetic medicineconsumption and the health of periodontal tissue of Prolanis DM patients type II in a community health center called Pusat Kesehatan Masyarakat (Puskesmas)Mranggen III. This research examines the health of periodontal tissue using CPITN index and gingiva index and status ofobedience in consuming antidiabetic medicine using Modified Morisky Scale questionnaire.
\end{abstract}

Method :The method of this research was analytic observation by using cross-sectional design. The samples were taken by using accidental sampling method. The test of the data analysis was done by using correlation test Spearman Rho (e).

Result :The total of sample was 36; the percentage of obedient patient $86.2 \%$ and non-obedient patient $13.8 \%$. Patients having healthy periodontal was $33.3 \%$, moderate $52.8 \%$, and poor $13.9 \%$. The correlation between the obedience of antidiabetic medicineconsumption and the health of periodontal tissue $(\mathrm{p}=0,000 ; \mathrm{p}<0,050)$

Conclusion : There was relationship between the obedience of antidiabetic medicineconsumption and the health of periodontal tissue.

Keywords: The obedience of antidiabetic medicineconsumption, The health of periodontal tissue, Prolanis DM patient 


\section{PENDAHULUAN}

Penyakit periodontal adalah suatu keadaan patologis yang mengenai jaringan periodontal. Anatomi dari jaringan periodontal terdiri dari gingiva, ligamen periodontal, sementum dan tulang alveolar. Faktor penyebab penyakit periodontal secara garis besar dapat dikelompokkan menjadi dua, yaitu faktor lokal dan faktor sistemik. Faktor lokal penyebab penyakit periodontal yaitu plak dan non plak ${ }^{1}$.

Periodontitis adalah penyakit jaringan periodontaldengan peradangan pada jaringan tersebut yang ditandai oleh epitel jungsional migrasi ke apikal, sehingga menyebabkan hilangnya perlekatan dan menurunnya puncak tulang alveolar serta terjadi perdarahan saat probing pada daerah tersebut ${ }^{2}$.

Gambaran jaringan periodontal secara histologi, memperlihatkan adanya infeksi karena kolonisasi bakteri pada poket periodontal. Karakteristik inflamasi jaringan periodontal yaitu terjadi kerusakan jaringan pendukung gigi, termasuk tulang alveolar dan ligamen periodontal. Produk dari mikroba memicu pelepasan proinflamatory cytokines dan enzim dari ligamen periodontal tersebut ${ }^{3}$.

Mikroorganisme yang melekat pada jaringan periodontal dapat di identifikasi di daerah interseluler epithelium. Contoh mikroorganisme patogen tersebut adalahP.Gingivalis, Aggregatibacter actinomycetemcomitans, Fusobacterium nucleatum dll. Bakteri yang telah melekat pada daerah subgingival, akan memberikan respon inflamasi berupa kerusakan gingiva dan jaringan periodontal. Struktur protein pada jaringan periodontal seperti kolagen, elastin dan fibronectin tersebutakan dirusak oleh mikroorganisme sehingga terjadi kerusakan pada struktur protein jaringan periodontal ${ }^{3}$.

Diabetes melitus (DM) dan penyakit periodontal merupakan penyakit dengan gangguan inflamasi kronis yang berdampak besar pada kesehatan dan kesejahteraan jutaan orang di seluruh dunia ${ }^{4}$. Diabetes Melitus dan periodontitis adalah penyakit yang saling berhubungan dan termasuk dalam penyakit kronis yang kompleks. Bukti bahwa kadar gula dalam darah yang tinggi pada penderita DM dikaitkan dengan kesehatan jaringan periodontal yang buruk ${ }^{4}$. Periodontitis biasanya terjadi pada penderita DM yang parah atau DM tidak terkontrol. Hasil klinis menunjukkan bahwa DM dan periodontitis memiliki pengaruh pada keduanya ${ }^{6}$.

Pasien yang memiliki riwayat penyakit DM akan memiliki manifestasi pada rongga mulutnya. Manifestasi yang cukup serius di bidang kedokteran gigi adalah oral diabetic, yang meliputi mulut kering, gusi mudah berdarah (gingivitis), kalkulus, resorbsi tulang alveolaris, periodontitis dan lain sebagainya. Penyakit periodontal yang sering dijumpai pada pasien DM adalah gingivitis dan periodontitis7. Periodontitis merupakan komplikasi yang paling sering terjadi pada penderita DM dengan tingkat prevalensi yang tinggi hingga mencapai angka $75 \%$. Pencegahan komplikasi dilakukan dengan cara menjaga kestabilan gula darah dengan pengobatan secara rutin seumur hidup karena DM merupakan penyakit seumur hidup yang tidak bisa disembuhkan secara permanen. Keadaan tersebut menyebabkan banyak pasien yang jenuh dan tidak patuh dalam pengobatan ${ }^{8}$. 
Ketidakpatuhan pasien meningkatkan risiko komplikasi dan bertambah parahnya penyakit DM yang diderita ${ }^{8}$. Hasil laporan WHO tahun 2003, rata-rata kepatuhan pasien terapi jangka panjang pada penyakit kronis di negara maju mencapai 50\%, sedangkan di negara berkembang lebih rendah. Keberhasilan terapi DM sangat dipengaruhi oleh kepatuhan pasien dalam menjalankan pengobatan'. Keparahan penyakit DM dapat dicegah dengan konsumsi obat antidiabetes ${ }^{10}$. Keberhasilan terapi dapat dilihat dari penurunan kadar gula darah puasa menjadi antara $70-130 \mathrm{mg} / \mathrm{dL}^{11}$.

PROLANIS singkatan dari program penggelolaan penyakit kronis yang merupakan sistem pelayanan kesehatan dan pendekatan proaktif yang dilaksanakan secara terintegrasi yang melibatkan peserta, fasilitas kesehatan dan BPJS Kesehatan dalam rangka pemeliharaan kesehatan bagi peserta BPJS Kesehatan yang menderita penyakit kronis (DM dan hipertensi) untuk mencapai kualitas hidup yang optimal dengan biaya pelayanan kesehatan yang efektif dan efisien ${ }^{12}$

\section{METODE PENELITIAN}

Jenis penelitian ini adalah observasi analitik dengan desain cross-sectional. Populasi penelitian sebanyak 53 orang peserta PROLANIS DM. Pengambilan 36 sampel dilakukan secaranonprobability sampling dengan teknik accidental sampling. Penelitian ini telah mendapatkan Ethical Clearance dari KEPK FKG Unissula No. 008/B.1-KEPK/SAFKG/III/2017. Tempat penelitian di Puskesmas Mranggen III, Kabupaten Demak. Pengambilan data pada bulan Maret - April 2017.
Analisis data yang digunakan yaitu analisis bivariat, untuk mengetahui hubungan antara variabel - variabel kepatuhan konsumsi obat antidiabetes dengan kesehatan jaringan periodontal. Kedua data tersebut di uji dengan menggunakan program SPSS dengan analisis

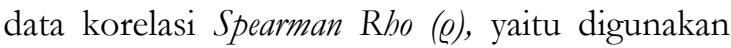
untuk dua variabel dengan skala data ordinal. Data primer yang digunakan berupa data yang diperoleh dengan pengamatan secaralangsung yaitu indeks CPITN dan indeks gigiva.

Alat dan bahan yang digunakan adalah diagnostic set (kaca mulut, pinset, sonde, eskavator), sarung tangan, masker, probe dengan ball tip 0,5 mm (WHO), povidone iodine, alkohol $70 \%$, dan kapas. Penelitian dimulai dengan memberikan inform consent ke pasien kemudian melihat rekam medis pasien PROLANIS untuk mengetahui identitas, dan kontrol glikemiknya. Setelah itu, melakukan wawancara mengenai kepatuhan konsumsi obat antidabetes dengan menggunakan kuisoner Modified Morisky Scale (MMS). Selanjutnya pemeriksaan untuk melihat dan mengukur jaringan periodontal dengan menggunakan probe periodontal untukmelihatindeks CPITN dan indeks gingiva. Kepatuhan konsumsiobat dihubungkan dengan kesehatan jaringan periodontal tiap pasien dengan uji korelasi Spearman Rho (œ).

Tingkat status periodontal dinilai dari hasil jumlah skor total indeks CPITN dibagi jumlah gigi yang diperiksa. Ketentuan skor untuk kriteria indeks CPITN yaitu 0 adalah untuk periodontium sehat, 1 adalah terdapat perdarahan setelah probing, 2 adalah terdapat kalkulus supra atau subgingiva atau timbunan plak di sekeliling margin gingiva, tidak terdapat poket dengan kedalaman lebih dari $3 \mathrm{~mm}, 3$ 
adalah Terdapat poket dengan kedalaman 4 atau $5 \mathrm{~mm}$, dan 4 adalah terdapat poket lebih dari 6 $\mathrm{mm}$.

Kondisi gingiva didapatkan dari jumlah skor total indeks gingiva dibagi jumlah gigi dikali jumlah permukaan yang diperiksa. Ketentuan skor untuk status gingiva yaitu 0 adalah gingiva normal, 1 adalah peradangan ringan terlihat sedikit perubahan warna dan sedikit edema, dan tidak ada perdarahan saat probing, 2 adalah peradangan sedang, warna gingiva kemerahan, adanya edema, dan perdarahan saat probing, dan 3 adalah Peradangan berat, warna merah terang atau merah menyala, adanya edema, ulserasi, kecenderungan adanya perdarahan spontan.

Kuisioner menggunakan pertanyaan yang di modifikasi dari Modified Morisky Scale (MMS), dengan total pertanyaan dalam kuisioner kepatuhan konsumsi obat antidiabetes berjumlah 6 poin. Butir pertanyaan nomor 1,2, dan 6 adalah pertanyaan mengarah ke motivasi pasien yang mengukur kelalaian dan kecerobohan yang dianggap sebagai indikasi motivasi dan dapat mempengaruhi dari niat kepatuhannya. Butir pertanyaan nomor 3,4, dan 5 adalah pertanyaan mengarah ke pengetahuan yang mengukur jika pasien menghentikan pengobatan dan memahami manfaat terapi lanjutan jangka panjang yang dianggap sebagai indikasi pengetahuan dan mempengaruhi aspek pengetahuan dari niat kepatuhannya ${ }^{13}$.

\section{HASIL}

Responden yang patuh konsumsi obat antidiabetes pada pasien PROLANIS DM tipe 2 di Puskesmas Mranggen III yaitu 86,1\%. Pasien yang patuh dalam konsumsi obat antidiabetes yaitu 31 dari total jumlah 36 pasien.

Hasil uji korelasi antara indeks CPITN, indeks gingiva dan kepatuhan konsumsi obat antidiabetes mendapatkan $\mathrm{P}=0,000 \quad(\mathrm{P}<0,050)$; $\mathrm{H}_{0}$ ditolak, terdapat hubungan antara kepatuhan konsumsi obat antidiabetes dengan kesehatan jaringan periodontal.

Gambar 1 menjelaskan hasil pemeriksaan jaringan periodontal dengan indeks CPITN pada pasien PROLANIS DM menunjukkan bahwa tingkat status periodontal terbanyak

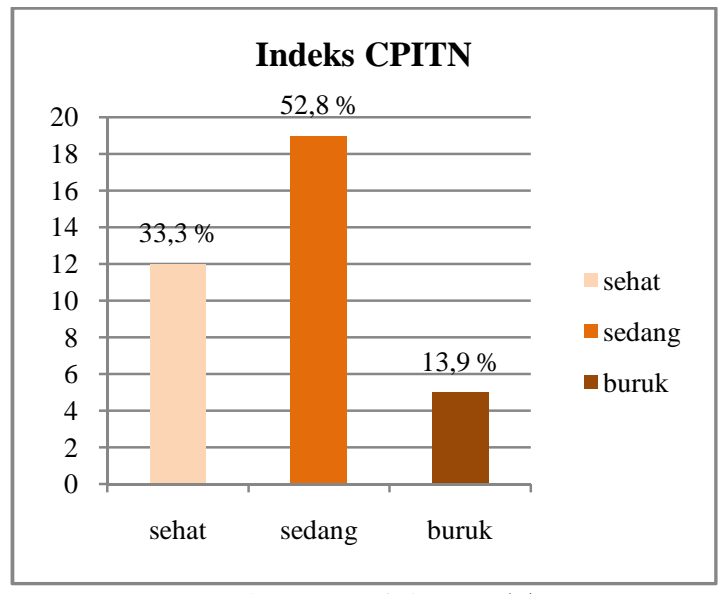

Gambar 1. Indeks CPITN

yaitu sedang kemudian sehat dan yang terakhir buruk. Tingkat status periodontal sehat menunjukkan bahwa pasien memiliki skor 0 , sedang 1-2, dan buruk 3-4.

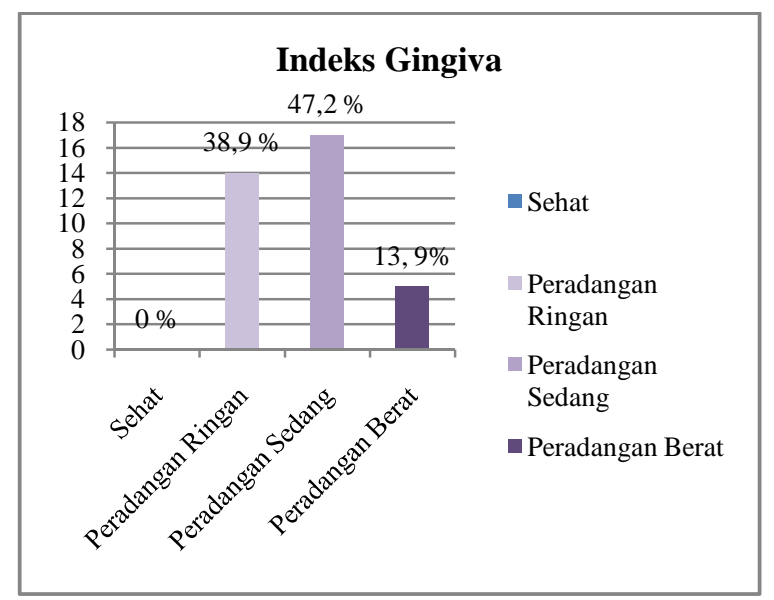

Gambar 2. Indeks Gingiva

Vol. 2 No.4Februari 2018 
Gambar 2 menjelaskan hasil pemeriksaan indeks gingiva pada pasien PROLANIS DM menunjukkan bahwa kondisi gingiva terbanyak adalah peradangan sedang, kemudian peradangan ringan, peradangan berat dan sehat. Kondisi gingiva sehat menunjukkan bahwa pasien memiliki skor 0; peradangan ringan 0,11,0; peradangan sedang 1,1-2,0; peradangan berat 2,1-2,0.

Tabel 1. Kepatuhan Konsumsi Obat dengan Indeks Gingiva

\begin{tabular}{|c|c|c|c|c|c|c|c|c|}
\hline \multirow{3}{*}{ Kepatuhan } & \multicolumn{8}{|c|}{ Kondisi Cringivn } \\
\hline & \multicolumn{2}{|c|}{ Sehat } & \multicolumn{2}{|c|}{$\begin{array}{c}\text { Peradangan } \\
\text { Ringan }\end{array}$} & \multicolumn{2}{|c|}{$\begin{array}{c}\text { Peradangan } \\
\text { Sedaring }\end{array}$} & \multicolumn{2}{|c|}{$\begin{array}{c}\text { Peradangan } \\
\text { Beral }\end{array}$} \\
\hline & $n$ & $\%$ & $n$ & $\%$ & $n$ & $9 / 11$ & $n$ & $m_{1}$ \\
\hline Patuh & 0 & 0 & 14 & 38,89 & 16 & 44,44 & 1 & 2,78 \\
\hline $\begin{array}{l}\text { Tidalk } \\
\text { Patuh }\end{array}$ & () & 0 & 0 & b) & 1 & $2, i k$ & 4 & 11,11 \\
\hline Jumlah & 0 & 0 & 11 & 38,89 & 17 & 17,22 & 5 & 13,89 \\
\hline
\end{tabular}

Tabel 1 memperlihatkan bahwa pasien yang patuh dalam konsumsi obat memiliki kondisi gingiva terbanyak yaitu peradangan sedang, kemudian peradangan ringan dan peradangan berat. Hasil tersebut menunjukkan kecenderungan bahwa pasien PROLANIS DM memiliki kondisi gingiva yang sudah mengalami peradangan.

Tabel 2. Kepatuhan Konsumsi Obat dengan Indeks CPITN

\begin{tabular}{ccccccc}
\hline \multirow{3}{*}{ Kepatuhan } & \multicolumn{4}{c}{ Tingkat Status Periodontal } \\
\cline { 2 - 7 } & \multicolumn{2}{c}{ Sehat } & \multicolumn{2}{c}{ Sedang } & \multicolumn{2}{c}{ Buruk } \\
\cline { 2 - 7 } & $\mathrm{n}$ & $\%$ & $\mathrm{n}$ & $\%$ & $\mathrm{n}$ & $\%$ \\
\hline Patuh & 11 & 30,56 & 18 & 50 & 2 & 5,55 \\
\hline $\begin{array}{c}\text { Tidak } \\
\text { Patuh }\end{array}$ & 1 & 2,78 & 1 & 2,78 & 3 & 8,33 \\
\hline Jumlah & 12 & 33,34 & 19 & 52,78 & 5 & 13,88 \\
\hline
\end{tabular}

Tabel 2 memperlihatkan bahwa pasien yang patuh dalam konsumsi obat memiliki tingkat status periodontal terbanyak yaitu sedang, sehat dan buruk. Hasil tersebut menunjukkan kecenderungan bahwa pasien PROLANIS DM memiliki tingkat status periodontal yang berbeda pada pasien. Perbedaan dipengaruhi oleh patuh atau tidaknya pasien dalam konsumsi obat antidiabetes, selain itu faktor lain seperti pengetahuan tentang kesehatan gigi dan mulut, tingkat pendidikan, usia, jenis kelamin juga mempengaruhi.

\section{PEMBAHASAN}

Kepatuhan merupakan suatu istilah yang digunakan untuk mengukur perilaku dalam konsumsi obat. Definisi kepatuhan menurut WHO tahun 2003, adalah sejauh mana perilaku seseorang dalam konsumsi obat, mengikuti diet, dan atau melaksanakan perubahan gaya hidup, sesuai dengan rekomendasi yang disepakati dari penyedia pelayanan kesehatan ${ }^{13}$. Keberhasilan terapi DM sangat dipengaruhi oleh kepatuhan pasien dalam menjalankan pengobatan'. Ketidakpatuhan pasien meningkatkan resiko komplikasi dan bertambah parahnya penyakit yang diderita ${ }^{8}$.

Hasil penelitian menujukkan adanya korelasi antara kepatuhan konsumsi obat antidiabetes dengan kesehatan jaringan periodontal. Pasien yang patuh dalam konsumsi obat antidiabetes memiliki tingkat kesehatan periodontal sehat sampai sedang dengan skor sehat 0 , dan sedang 1-2, sedangkan untuk kondisi gingiva dalam keadaan sehat sampai peradangan sedang, dengan skor sehat 0 dan peradangan sedang 1,1 - 1,0. Pasien yang tidak patuh dalam konsumsi obat antidiabetes memiliki tingkat kesehatan periodontal yang sedang sampai buruk, dengan skor sedang 1-2 dan buruk 3-4, sedangkan untuk kondisi gingiva 
pada pasien yang tidak patuh yaitu peradangan berat dengan skor 2,1 - 3,0.

Pada penelitian Wiwik Salistraningsih (2011), menunjukkan bukti bahwa terdapat hubungan yang signifikan antara pasien yang patuh dan tidak patuh dalam konsumsi obat bipoglikemik oral dengan kadar glukosa darah pasien DM tipe 2, yaitu pasien yang patuh memiliki kadar glukosa darah normal dan pasien yang tidak patuh memiliki kadar glukosa darah tinggi $1^{15}$.

Hyperglycemia selalu berpotensi memberikan pengaruh pada poket periodontal. Diabetes melitus meningkatkan konsentrasi glukosa darah di lingkungan lokal gingival crevicular fluid (GFC) pada manusia dan menurunkan tingkat faktor perkembangan epidermal saliva. Tingginya konsentrasi kadar glukosa dapat menyebabkan kerusakan secara tidak langsung, melalui hasil akhir dari produk glukosa (AGE's), dan kerusakan sel langsung, hasil stimulasi intracellular patbways. Advance Glycation End Product menyebabkan penurunan sintesis kolagen, meningkatkan MMPs (matrix metalloproteinase) yang merupakan mediator utama dalam degredasi kolagen, dan juga menurunkan extracellular matrix sehingga menyebabkan gangguan pada fungsi seluler, perubahan vascular, peradangan yang semakin parah, gangguan pada pembentukan atau perbaikan tulang dan gangguan penyembuhan luka pada jaringan periodontal sehingga dapat menyebabkan periodontitis ${ }^{16}$.

Periodontitis biasanya terjadi pada penderita DM yang parah atau diabetes tidak terkontrol. Hasil klinis menunjukkan bahwa DM dan periodontitis memiliki pengaruh pada keduanya $^{6}$. DM dan periodontitis adalah penyakit yang saling berhubungan dan termasuk dalam penyakit kronis yang kompleks. Bukti bahwa kadar gula dalam darah yang tinggi pada penderita DM dikaitkan dengan kesehatan jaringan periodontal yang buruk ${ }^{4}$.

\section{SIMPULAN}

Hasil uji korelasi dilakukan dengan Uji

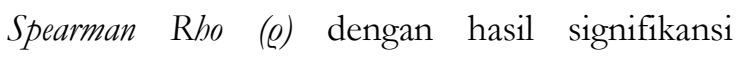
periodontalnya $\quad 0,000 \quad(\mathrm{p}<0,05) \quad$ dapat disimpulkan terdapat hubungan antara kepatuhan konsumsi obat antidiabetes dengan kesehatan jaringan periodontal. Kepatuhan konsumsi obat akan mempengaruhi dari kadar gula darah pasien, sehingga akan berefek pada kesehatan jaringan

\section{DAFTAR PUSTAKA}

1. Suryono. Bedah Dasar Periodonsia. 1 ed. Yogyakarta: Deepublish; 2014. 2 hal.

2. Fedi PF, Vernino AR, Gray JL. Silabus Periodonti. 4 ed. Juwono L, editor. Jakarta: EGC; 2004.

3. Newman Michael G., H. TH, Klokkevold PR, Carranza FA. Carranza's Clinical Periodontology. 11 ed. Missouri: Elsavier Saunders; 2012.

4. Sharma M, Jindal R, Siddiqui MA, Wangnoo SK. Diabetes and Periodontitis: A medical perspective. J Int Clin Dent Res Organ. 2016;8(1).

5. Mealey BL, Oates TW. Diabetes Melitus and Periodontal Disease. J Periodontol. 2006;77(8).

6. Chee B, Park B, Bartold P. Periodontitis type II diabetes: A two - way relationship. Int J Evid Based Heal. 2013;11(3):17-29.

7. Andersen CCP, Flyvbjerg A, Buschard K, Holmstrup P. Relationship Between 
Periodontitis and Diabetes: Lessons from Rodent Studies. J Periodontol. 2007;78(7):1264-75.

8. Sri Hidayati. Analisis faktor yang berhubungan dengan tingkat keparahan periodontitis pada penderita DM tipe 2 di poli diabetes RSU dr. Soetomo Surabaya. Bul Penelit RSU dr Soetomo. 2008;10(2):10-2.

9. Pratita ND. Hubungan Dukungan Pasangan dan Health Locus of Control dengan Kepatuhan dalam Menjalani Proses Pengobatan Pada Penderita Diabetes Mellitus Tipe 2. J Ilm Mhs Univ Surabaya. 2012;1(1).

10. BPOM. Kepatuhan Pasien: Faktor Penting Dalam Keberhasilan Terapi. Vol. 7. Jakarta: Badan POM Republik Indonesia; 2006.

11. Ambarwati WN. Konseling Pencegahan dan Penatalaksanaan Pederita Diabetes Melitus. Publ Ilmiah, Univ Muhammadiyah Surakarta. 2012;

12. Pascal I., Ofoedu JN, Uchenna NP, Nkwa AA, Uchamma G. Blood Glucose Control and Medication Adherence Among Adult Type 2 DIabetic Nigerians Attending a Primary Care CLinic in Under-resourced Environment of Eastern Nigeria. North Am J Med Sci. 2012;4(7).

13. BPJS Kesehatan. Panduan Praktis PROLANIS (Program Pengelolaan Penyakit Kronis). In 2014. hal. 1-18.

14. Case Management Society of America. Case Management Adherence Guidline. 2006;71-5.

15. Tambunan EGR, Pandelaki K, Mintjelungan CN. Gambaran Penyakit Periodontal pada Penderita Diabetes Melitus di Rumah Sakit Umum Pusat Prof. Dr. R. D. Kandou Manado. J eGigi. 2015;3(2).

16. Salistyaningsih W, Puspitawati T, Nugroho DK. Hipoglik, Kepatuhan Minum Obat Hipoglikemik Oral dengan Kadar Glukosa Darah pada Pasien Diabetes Melitus Tipe 2. Ber Kedokt Masy. 2011;27(4). 